\title{
Keragaman Fungsi dan Bentuk Spasial Pertanian Kota (Studi Kasus: Pertanian Kota di Jakarta)
}

\author{
Hayuning Anggrahita ${ }^{1}$ \\ Departemen Geografi, Fakultas Matematika dan IImu Pengetahuan Alam \\ Universitas Indonesia, Depok, Indonesia
}

\section{Guswandi Guswandi}

Fakultas Ekonomi dan Bisnis, Universitas Sultan Ageng Tirtayasa

Serang, Indonesia

Artikel Masuk : 15 Desember 2017

Artikel Diterima : 26 April 2018

Tersedia Online : 31 Desember 2018

\begin{abstract}
Abstrak: Urbanisasi di Jakarta mendorong konversi lahan-lahan pertanian dan ruang terbuka hijau lainnya menjadi lahan terbangun. Pertanian menjadi terdesak dan kontribusinya hanya sebesar 0,1\% dalam perekonomian Jakarta. Penelitian ini menemukan bahwa walaupun kontribusinya kecil, namun pertanian kota di Jakarta mampu bertahan dari kepunahan karena bertransformasi dengan cara memperluas fungsi pertanian dari hanya fungsi tunggal sebagai penyedia pangan, khususnya pokok, menjadi berfungsi jamak (multifungsi) seperti fungsi lingkungan, fungsi kultural, fungsi penjaga klaim properti, dan lain-lain. Penelitian ini bertujuan untuk mengidentifikasi keragaman fungsi pertanian perkotaan Jakarta yang termanifestasi dalam ruang (space). Untuk mencapai tujuan tersebut, penelitian ini menggunakan metode analisis kuantitatif deskriptif dan diperdalam dengan analisis kualitatif. Penggunaan interpretasi citra digunakan untuk mengidentifikasi lokasi dan luas pertanian perkotaan Jakarta. Selain itu, survei lapangan (fieldwork) dilaksanakan untuk mendapatkan representasi realitas fisik dan sosial di lapangan. Hal itu dilakukan dengan dua teknik, yaitu observasi dan fotografi ilmiah. Hasil penelitian ini menunjukkan bahwa pertanian Jakarta tersebar (scattered) akibat tekanan urbanisasi dan mempunyai fungsi yang beragam. Selain itu, pertanian Jakarta bertransformasi melalui penciptaan nilai-nilai baru perkotaan yang menunjukkan kemampuan pertanian perkotaan bertahan dalam keragaman bentuk spasial yang khas.
\end{abstract}

Kata Kunci: keragaman bentuk spasial; keragaman fungsi pertanian; konversi lahan pertanian; pertanian perkotaan; urbanisasi

Abstract: Urbanization in Jakarta encourages the conversion of agricultural land and other green open spaces into built-up areas. Agriculture sector is being marginalized and its contribution is only $0.1 \%$ of the economy of Jakarta. Previous studies showed that regardless of its fewer contribution, Jakarta's agriculture persistence takes place due to single to multiple functional transformations especially from staple food production to diverse functions such as environmental, cultural, property rights protection functions, etc. This study aims to identify agricultural multi-functionality in Jakarta. This research uses descriptive quantitative analysis

\footnotetext{
${ }^{1}$ Korespondensi Penulis: Departemen Geografi, Fakultas Matematika dan Ilmu Pengetahuan Alam

Universitas Indonesia, Depok, Indonesia

email: hayuning.anggrahita@gmail.com
} 
method which is deepened with qualitative analysis through the interview and scientific photography technique to represent physical and social reality in the field. The results indicate that Jakarta's agriculture is scattered due to urbanization pressure. In addition, Jakarta's agriculture is transformed through the creation of new urban values which demonstrate the ability of urban agriculture to survive.

Keywords: agricultural land conversion; agricultural multifunctionality; spatial form variation; urban agriculture; urbanization

\section{Pendahuluan}

Urbanisasi yang didorong oleh migrasi dari perdesaan ke perkotaan menyebabkan perkembangan kawasan perkotaan seperti Jakarta menjelma menjadi kota metropolitan. Sebagai kota besar, aktivitas ekonomi Jakarta didominasi oleh sektor industri dan jasa. Pertanian di Jakarta semakin lama semakin menurun dan menjadi aktivitas marjinal. Hal tersebut ditunjukkan dari penurunan jumlah rumah tangga pertanian yang cukup signifikan dalam 10 tahun terakhir, yaitu sebesar 76,63\% dibandingkan dengan tahun 2003 (BPS Provinsi DKI Jakarta, 2014). Namun demikian, kondisi ini bukan berarti aktivitas pertanian perkotaan di Jakarta benar-benar mati, karena sektor pertanian memiliki kontribusi sebesar 0,1\% dalam perekonomian Jakarta (BPS Provinsi DKI Jakarta, 2013). Hal ini dibuktikan dengan penurunan jumlah rumah tangga pertanian, namun masih terdapat 18.216 rumah tangga yang bergantung pada sektor pertanian (BPS Provinsi DKI Jakarta, 2013). Hal tersebut menunjukkan bahwa aktivitas pertanian perkotaan di Jakarta memiliki potensi sebagai sumber pendapatan bagi sebagian penduduk Jakarta, terutama bagi mereka yang kesulitan mendapat pekerjaan di sektor formal karena keterbatasan sumber daya dan keahlian yang dimiliki (BPS Provinsi DKI Jakarta, 2014). Namun demikian, potensi tersebut tidak dianggap signifikan dalam Rencana Tata Ruang Wilayah Nasional (RTRWN) 2008, Jakarta ditetapkan sebagai kawasan metropolitan. Definisi fungsional kawasan tersebut adalah wilayah perkotaan yang mempunyai kegiatan utama bukan pertanian (Pemerintah Republik Indonesia, 2008), sehingga penggunaan lahan pertanian selalu kalah bersaing dengan penggunaan lahan kawasan metropolitan, seperti permukiman, pusat pemerintahan, kegiatan ekonomi, dan pelayanan sosial. Selain itu, anggapan bahwa potensi pertanian kota tidak signifikan juga disebabkan oleh kurangnya pemahaman akan beragamnya fungsi pertanian perkotaan yang dapat mendukung keberlanjutan kota, terutama di Negara Berkembang seperti di Antananarivo (Madagaskar) (Aubry et al., 2012; Pribadi \& Pauleit, 2016). Sementara itu, menurut Aubry et al. (2012), penyajian representasi pertanian perkotaan dan pengidentifikasian fungsi-fungsi pertanian perkotaan merupakan langkah awal yang penting dalam menentukan peran pertanian dalam pembangunan kota yang berkelanjutan dan melakukan perencanaan kota yang baik.

Seiring dengan perkembangan zaman dan teknologi, serta adanya perubahan kebutuhan manusia, fungsi pertanian tidak hanya terbatas pada fungsi tradisional, yaitu sebagai produsen dan pemasok atau penyedia produk pertanian (Li et al., 2015; Wu, Verburg, \& Tang, 2014), tetapi juga mempunyai fungsi lain yaitu fungsi ekonomi dan fungsi nonekonomi. Fungsi ekonomi meliputi fungsi livelihood (Dubbeling, de Zeeuw, \& van Veenhuizen, 2010), fungsi penopang ekonomi rumah tangga (Purnomohadi, 1998), dan fungsi penghasilan (Peng, Liu, Liu, Hu, \& Wang, 2015). Adapun fungsi nonekonomi meliputi fungsi ekologi/lingkungan (Perring et al., 2012) dan fungsi sosial-budaya (Peng et al., 2015). Namun, fungsi-fungsi tersebut lebih menjadi isu di tingkat internasional daripada di tingkat lokal (Drechsel \& Dongus, 2010).

Sementara itu, Pemerintah Provinsi DKI Jakarta mulai menyadari pentingnya pertanian sebagaimana dinyatakan dalam Rencana Pembangunan Jangka Menengah (RPJM) DKI Jakarta 2018-2022 pada tujuan ketiga dalam misi kedua sebagai berikut: 
"Mewujudkan ketahanan pangan yang terjangkau, memadai, berkualitas, dan berkelanjutan". Pemerintah Provinsi DKI Jakarta menetapkan sebuah program yaitu "Program Pengembangan Pertanian, Peternakan dan Kesehatan Hewan" (BAPPEDA Provinsi DKI Jakarta, 2018). Pengembangan pertanian di perkotaan tentunya akan berbeda dengan di perdesaan. Pertanian perkotaaan tersebut menempati ruang-ruang yang terbatas di Provinsi DKI Jakarta yang menyebabkan kompetisi dengan penggunaan lahan lainnya. Hal tersebut menciptakan keragaman bentuk-bentuk spasial pertanian perkotaan yang khas dan berbeda dari pertanian di perdesaan (Nahmias \& Le Caro, 2012). Oleh karena itu, identifikasi fungsi-fungsi dan bentuk-bentuk spasial pertanian perkotaan mendesak untuk dilakukan dalam rangka berkontribusi dalam perencanaan pembangunan kota yang berkelanjutan di Provinsi DKI Jakarta. Berdasarkan kondisi tersebut, tujuan penelitian ini adalah untuk mengidentifikasi keragaman bentuk spasial pertanian perkotaan dan fungsi yang dilayani oleh pertanian perkotaan.

\section{Metode Penelitian}

\section{Batasan Penelitian}

Keragaman fungsi dan bentuk spasial pertanian perkotaan dapat diidentifikasi secara holistik dan komprehensif apabila dilakukan dalam skala wilayah yang luas, bukan dalam cakupan wilayah atau studi kasus yang sempit. Oleh karena itu, batasan penelitian ini adalah seluruh wilayah administrasi Provinsi DKI Jakarta kecuali Kepulauan Seribu, karena daerah tersebut bukan merupakan wilayah perkotaan. Selain itu fokus penelitian ini adalah keragaman fungsi dan bentuk spasial dari pertanian perkotaan di Provinsi DKI Jakarta dan bukan berdasarkan kegiatan subsektor pertanian. Keragaman fungsi pertanian adalah pelayanan atau keuntungan yang bisa disediakan oleh penggunaan tanah pertanian di perkotaan (Lovell, 2010). Adapun keragaman bentuk spasial adalah hasil manifestasi keragaman fungsi pertanian perkotaan yang menempati ruang-ruang yang terbatas (Nahmias \& Le Caro, 2012).

\section{Metode Pengumpulan Data}

Metode yang digunakan dalam penelitian ini adalah metode kuantitatif dengan analisis kuantitatif deskriptif dan analisis spasial kemudian diperdalam dengan analisis kualitatif. Lokasi daerah pertanian yang masih ada di Jakarta ditunjukkan melalui data penggunaan lahan tahun 2008 dari Badan Informasi Geospasial (BIG) yang diolah dan ditampilkan lokasi daerah pertaniannya. Data penggunaan lahan BIG hanya sampai pada tingkat "pertanian", sedangkan data spasial subsektor pertanian, seperti areal padi, sayurmayur, dan buah-buahan tidak tersedia. Lokasi daerah pertanian, khususnya pertanian padi sawah, dilihat melalui interpretasi citra Google Earth tahun 2015 dan dilakukan untuk menentukan sawah yang masih ada di Jakarta.

Analisis kuantitatif deskriptif dilakukan pada data statistik Sensus Pertanian tahun 2013 dari BPS untuk memberikan gambaran umum mengenai produktivitas pertanian padi sawah di Jakarta. Analisis keragaman fungsi dan keragaman bentuk spasial pertanian perkotaan di Provinsi DKI Jakarta dilakukan melalui wawancara dengan peneliti pertanian perkotaan dan Dinas Ketahanan Pangan, Kelautan dan Pertanian (DKPKP). Berdasarkan hasil wawancara tersebut, survei lapangan (fieldwork) dilaksanakan untuk mendapatkan representasi realitas fisik dan sosial di lapangan. Selain itu, survei lapangan juga dilakukan menggunakan fotografi ilmiah. Dalam penelitian ini, fotografi digunakan untuk mendapatkan data primer tentang realitas situasi dan kondisi keragaman fungsi dan keragaman bentuk spasial pertanian Jakarta langsung dari lapangan. Secara teknis penggunaan fotografi dalam penelitian geografi dan perencanaan wilayah mudah, sederhana, dan murah karena bisa menggunakan kamera apa saja untuk menghasilkan foto, 
namun di Indonesia penggunaannya kurang populer dibanding dengan Geographical Information System (GIS) dan penginderaan jauh (remote sensing) yang dianggap lebih canggih. Namun demikian, fotografi sangat berguna dan bahkan telah dianggap sebagai cara klasik yang punya sejarah panjang karena keefektifannya khususnya dalam merepresentasikan suatu kota (Butler, 1994; Rose, 2008; Sidaway, 2002). Dengan mempertimbangkan alasan mudah, sederhana, murah, namun tetap efektif, penelitian ini menggunakan fotografi. Adapun tahapan dalam analisis fotografi adalah setelah keragaman bentuk-bentuk spasial pertanian perkotaan diidentifikasi berdasarkan hasil wawancara dengan ahli dan dinas terkait, dilakukan survei lapangan ke lokasi pertanian untuk mengidentifikasi bentuk-bentuk spasial. Setelah itu, dilakukan pemotretan untuk memberikan gambaran atas realitas fisik di lapangan dan peneliti melakukan penyajian foto secara visual dan melakukan deskripsi dari gambaran visual tersebut.

\section{Hasil dan Pembahasan}

\section{Terdesaknya Pertanian Perkotaan}

Pertumbuhan urbanisasi di Jakarta yang cepat menimbulkan keraguan tentang masa depan pertanian Jakarta. Urbanisasi mendorong konversi lahan tak terbangun menjadi lahan terbangun. Sektor pertanian dianggap tidak cocok bagi perkembangan kota. Daerah pertanian bergeser jauh ke luar kota atau mendekati pinggiran kota (urban peripheries).

Logika yang mendasari ini adalah perluasan dari prinsip ilmu ekonomi klasik/neoklasik yaitu konsep sewa lahan (land rent). Prinsip ekonomi murni ini kemudian ditambahi dimensi fisik ruang, sehingga dalam jangka panjang keseimbangan akan tercapai antara produktivitas ekonomi tanah dan harga tanah secara spasial. Term of trade yang cenderung rendah dari produk-produk pertanian dibandingkan produk-produk industri dan jasa membuat aktivitas pertanian dianggap tidak kompetitif dilakukan di perkotaan. Dengan logika ekonomi seperti ini, pertanian perkotaan akan bergeser secara alamiah lewat interaksi permintaan dan penawaran tanah (mekanisme pasar).

Selain itu, pertanian perkotaan juga dapat bergeser akibat kebijakan publik yang tidak berpihak kepadanya. Adanya bantuan pemerintah yang percaya dengan inefisiensinya, pemerintah sendiri yang menginginkan pembangunan diprioritaskan di sektor-sektor dan/atau daerah-daerah yang menguntungkan sehingga pertanian perkotaan harus mengalah, dan konsekuensinya bergeser ke luar kota.

Dalam konteks Indonesia termasuk Jakarta, pertanian perkotaan selama ini kurang mendapatkan perhatian cukup. Sejak Presiden Soeharto berkuasa di akhir dekade 1960-an, fokus pemerintah Indonesia di sektor pertanian adalah pembangunan ekonomi perdesaan (rural development) yang berbasis pertanian perdesaan (rural agriculture). Presiden Soeharto dianggap berhasil meningkatkan ketahanan pangan nasional lewat kebijakan revolusi hijau (green revolution) yang meningkatkan produksi pertanian pangan utama khususnya beras (Mubyarto, 1983; Mubyarto \& Kartodirdjo, 1988). Namun, Pemerintah Indonesia dan Pemerintah DKI Jakarta saat itu kurang tertarik pada revitalisasi pertanian perkotaan (Sujarto \& Karyoedi, 1996). Logika tersebut tentunya mendorong pertanian perkotaan cepat atau lambat akan mati.

Logika sebaliknya, yaitu merevitalisasi pertanian perkotaan, terlihat seperti tidak pantas memiliki tempat dalam ranah kebijakan publik yang bersifat praktis dan dalam dunia ilmiah karena alasan sederhana, berlawanan dengan logika klasik/neoklasik. Dalam hegemoni logika ini, revitalisasi pertanian perkotaan yang dapat dibagi ke dalam dua bagian penting, yaitu mempertahankan dan kemudian membangunnya, terlihat tidak memiliki kemampuan dan kapasitas dalam hal memproduksi untuk memenuhi kebutuhankebutuhan wilayah kota itu sendiri. 


\section{Keragaman Fungsi Pertanian Perkotaan}

Pertanian perkotaan di Jakarta memang terdesak karena alasan alamiah. Penyebab utamanya adalah urbanisasi, dan alasan nonalamiah yaitu kurangnya perhatian pemerintah terhadap pertanian perkotaan yang tercermin dalam kebijakan publik yang telah ditetapkan (Campbell, 2016). Namun pertanian perkotaan mampu bertahan dan tidak mati. Ini disebabkan oleh kemampuan pertanian perkotaan memperluas fungsi pertanian di tengah berbagai faktor yang menghambatnya (Mollard, 2003). Selain itu, pertanian perkotaan memberikan eksternalitas positif, yang dalam konteks pertanian didefinisikan sebagai perubahan dalam lingkungan fisik dan sosial, yang disebabkan oleh aktivitas usaha pertanian yang memberikan tambahan nilai dan melampaui sistem produksinya baik secara langsung maupun tidak langsung. Eksternalitas positif ini diterjemahkan dalam prosesproses berkembangnya fungsi tunggal pertanian, yaitu pada penyediaan pangan khususnya beras menjadi memiliki juga fungsi-fungsi lain seperti fungsi ekologi dan fungsi sosial, atau dengan kata lain keragaman fungsi pertanian perkotaan. Dalam hal ini, pertanian awalnya berfungsi sebagai penyedia pangan. Secara khusus fungsi ini berkaitan erat dengan pemenuhan kebutuhan karbohidrat sebagai makanan pokok. Di Pulau Jawa, khususnya di Jakarta, secara umum beras adalah sumber pangan pokok yang utama. Fungsi pangan pertanian perkotaan lainnya adalah sebagai penyedia pangan nonpokok seperti sayuran dan buah-buahan (hortikultura). Seiring dengan perkembangan teknologi dan zaman, fungsi pertanian perkotaan kemudian berkembang melampaui fungsi pertanian "tradisional" sebagai penyedia pangan pokok. Namun perlu dicatat bahwa fungsi penyedia pangan termasuk beras masih tetap bertahan. Adapun fungsi pertanian sebagai penyedia pangan dan fungsi-fungsi lain pertanian perkotaan yang ditemukan di Jakarta akan dielaborasi pada subbagian berikut ini. Adapun distribusi pertanian perkotaan dapat dilihat pada Gambar 1.

\section{Bertahannya Fungsi Penyedia Pangan}

Keberadaan pertanian perkotaan Jakarta sebagai penyedia pangan pokok masih dapat ditemukan walaupun kurang mendapatkan perhatian dari pemerintah Indonesia. Hal ini dapat dibuktikan dengan adanya keberadaan pertanian padi sawah di Jakarta walaupun jumlahnya tidak terlalu banyak. Padi adalah tanaman yang membutuhkan media tanam yang khusus yaitu petak sawah dan membutuhkan air yang cukup agar dapat tumbuh baik, sehingga menghasilkan panen dengan produktivitas yang tinggi. Kondisi yang demikian mengakibatkan pertanian padi tidak dapat ditanam di semua tempat bahkan pada saat lahan cukup tersedia. Keberadaan sawah produktif di Jakarta membuktikan bahwa pertanian pangan meneruskan fungsi tradisionalnya dalam memberikan pangan bagi penduduk Jakarta. Oleh karena itu, fungsi pertanian padi sebagai penyedia makanan pokok utama perlu mendapat perhatian khusus.

Di Jakarta, urbanisasi mendorong konversi lahan yang cepat, namun ternyata sawah yang dialiri irigasi masih ditemukan. Keberadaan jaringan irigasi ini berkat kontribusi daerah tetangga Jakarta. Jaringan irigasi ini masuk dalam jaringan irigasi Citarum Barat yang berujung pada Bendungan Jatiluhur di Jawa Barat. Namun, tidak ada pembangunan baru irigasi, yang ada adalah saluran-saluran irigasi di masa lalu. Namun, kebanyakan saluran itu sudah berganti dengan lahan terbangun atau terputus satu dengan lainnya karena dipisahkan lahan terbangun sehingga tidak lagi berfungsi sebagai saluran irigasi. Sawah-sawah Jakarta yang berjumlah 1.137 hektar pada tahun 2015 (Kementerian Pertanian Republik Indonesia, 2016), tidak semuanya bersaluran irigasi, dan ada pula sawah nonirigasi (tadah hujan). 


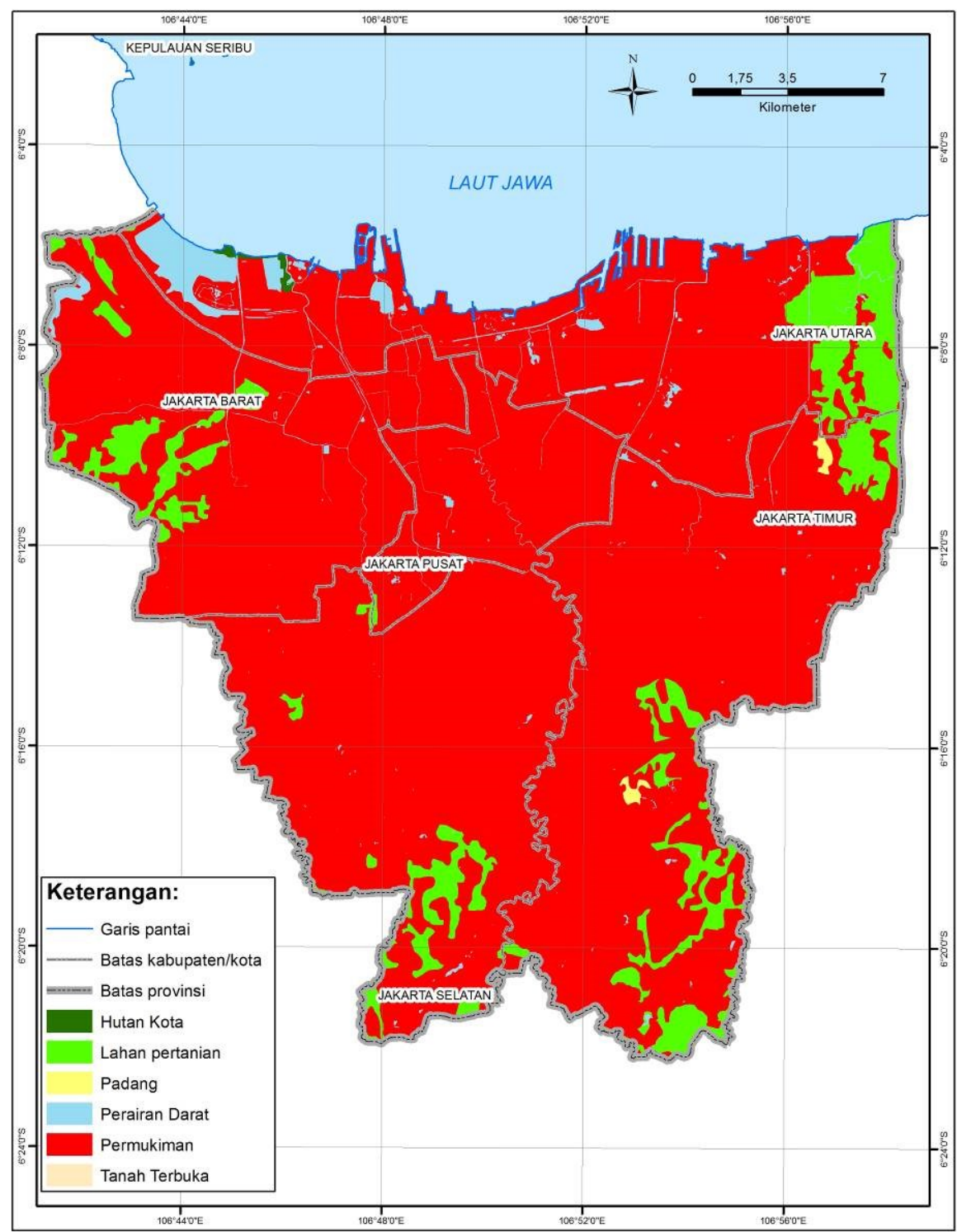

Sumber: Badan Informasi Geospasial, 2008

Gambar 1. Distribusi Lahan Pertanian di Provinsi DKI Jakarta

Menurut Stasiun Klimatologi Pondok Betung (2010), curah hujan Jakarta relatif tinggi yaitu $2.500 \mathrm{~mm}$ per tahun, sehingga cocok untuk pertanian padi yang membutuhkan lahan basah agar produktivitasnya tinggi. Hal tersebut merupakan faktor fisik penting yang membantu bertahannya pertanian padi. Namun, perlu dicatat bahwa curah hujan di Jakarta tidak terdistribusi merata. Secara umum, ada bulan-bulan yang curah hujannya tinggi pada musim penghujan dan ada bulan-bulan yang curah hujannya rendah pada musim kemarau.

Selain faktor-faktor fisik pendukung pertanian padi, keberadaan petani-petani padi merupakan hal yang terpenting. Pertanian padi di Jakarta ternyata tidak dilakukan oleh etnis Betawi, tetapi dilakukan oleh etnis pendatang yang berasal dari bermacam-macam daerah di Jawa. Sebelum bermigrasi ke Jakarta, petani-petani ini menanam padi di daerah asalnya (Purwanto, 2010).

Data statistik menunjukkan bahwa total luas lahan Provinsi DKI Jakarta adalah 66.100 hektar dengan luas pertanian padi 1.137 hektar, atau sama dengan 1,7\% dari luas total lahan Jakarta. Selain itu, luas lahan pertanian padi di Jakarta memiliki kecenderungan 
semakin kecil. Secara statistik, perlu dicatat bahwa statistik Kementerian Pertanian menyediakan data luas panen, bukan luas lahan (Gambar 2). Namun, luas panen dapat kita jadikan proxy dari luas lahan, dengan mengasumsikan bahwa kegagalan panen tidak signifikan berpengaruh terhadap total produksi.

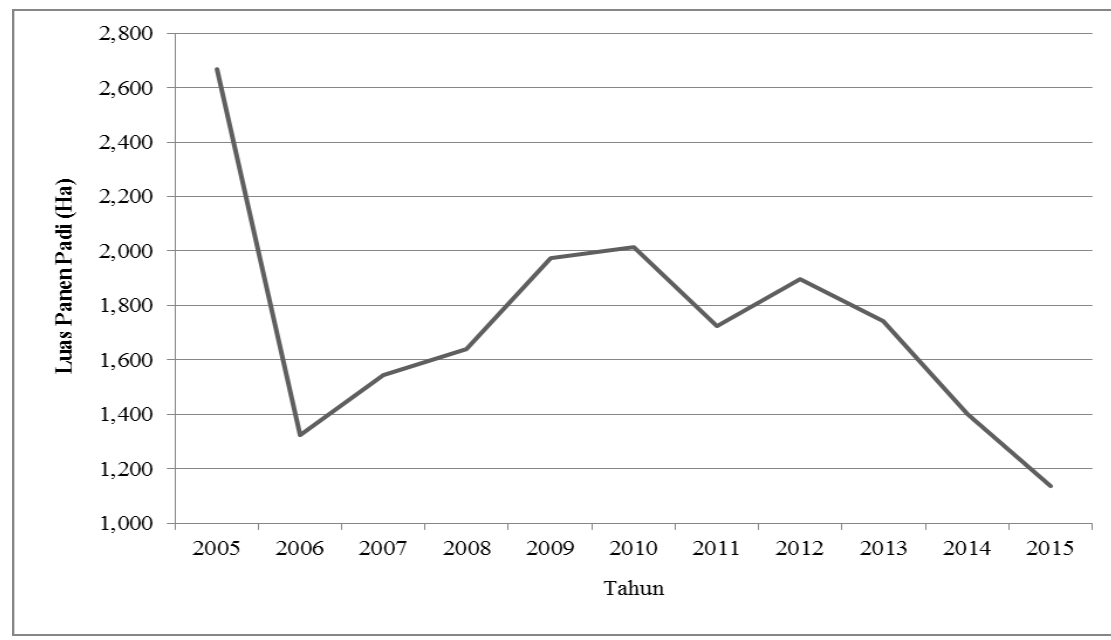

Sumber: Kementerian Pertanian, 2016

\section{Gambar 2. Luas Panen Tanaman Padi di Jakarta Tahun 2005-2015}

Penurunan luas panen tanaman padi tersebut mengakibatkan penurunan produksi padi (Gambar 3). Pertanian padi menjadi sangat marjinal karena tekanan urbanisasi. Hal tersebut menyebabkan petani tidak dapat memiliki sawahnya, tetapi mereka hanya menguasainya (mengelola dan menggarap). Pemilik tanah memberikan hak mengolah lahan kepada petani. Selain itu, lokasi sawah di Jakarta tidak terkonsentrasi (scattered) petak-petak sawahnya. Berdasarkan hasil interpretasi dan digitasi Citra Quick Bird Google Earth, lokasi sawah-sawah tersebut terdapat di Kota Jakarta Utara, Kota Jakarta Timur, dan Kota Jakarta Barat. Sementara itu, Kota Jakarta Pusat dan Kota Jakarta Selatan tidak memiliki sawah sama sekali (Gambar 4).

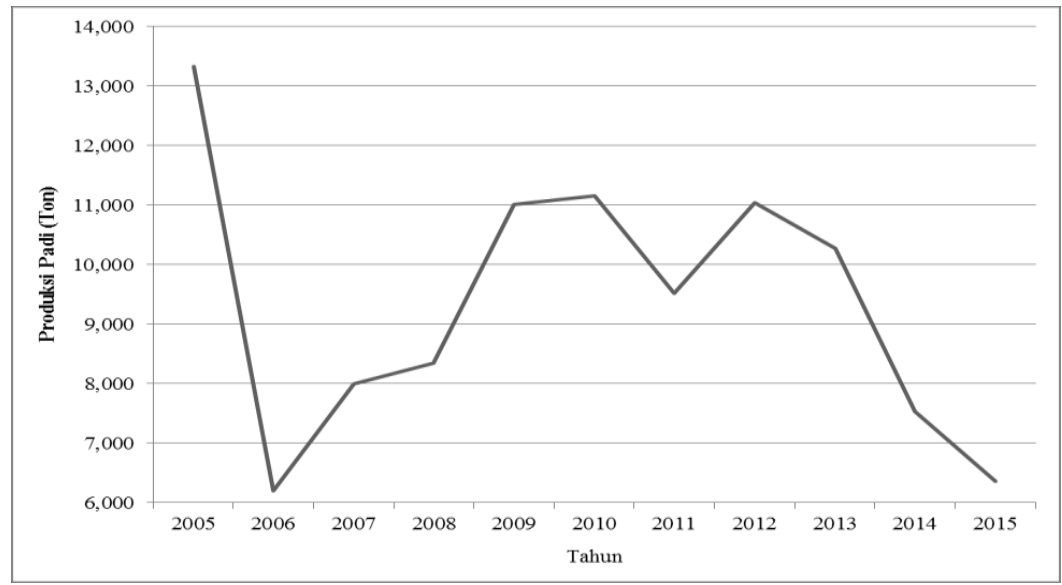

Sumber: Kementerian Pertanian, 2016

Gambar 3. Produksi Tanaman Padi di Jakarta Tahun 2005-2015 


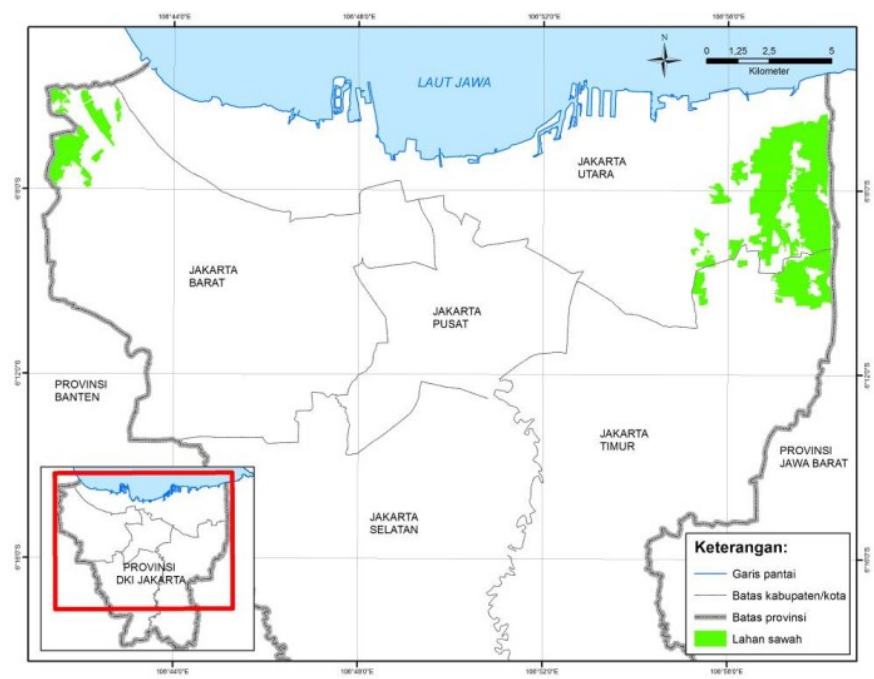

Sumber: Interpretasi dan Digitasi Citra Quick Bird Google Earth, 2015

\section{Gambar 4. Distribusi Lahan Sawah di Jakarta Tahun 2015}

Jumlah rumah tangga petani di Jakarta dari berbagai kategori penguasaan lahan menurun. Penurunan terbesar terjadi pada keluarga petani berlahan kurang dari 0,1 hektar yang berjumlah lebih dari 45 ribu keluarga petani merujuk hasil Sensus Pertanian 2003 menjadi di bawah 10.000 keluarga petani pada tahun 2013 (BPS Provinsi DKI Jakarta, 2013). Angka penguasaan lahan 0,1 hektar dapat dikategorikan sebagai keluarga petani sangat gurem (very small peasants). Hal ini bahkan jauh di bawah angka minimum untuk mengkategorikan keluarga petani gurem (small peasants) yaitu penguasaan lahan kurang dari 0,5 hektar per keluarga (Gambar 5). Selain itu, dari kategori sawah dan nonsawah, ratarata penguasaan sawah keluarga petani relatif kecil $499 \mathrm{~m}^{2}$, sedangkan penguasaan nonsawah keluarga petani sedikit lebih tinggi yaitu $1.025 \mathrm{~m}^{2}$.

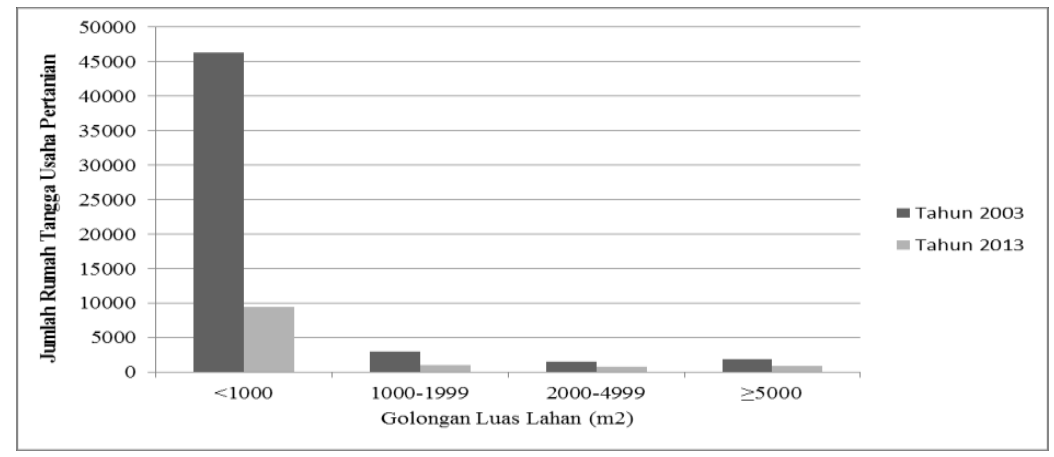

Sumber: Sensus Pertanian BPS, 2013

\section{Gambar 5. Jumlah Usaha Pertanian Menurut Golongan Luas Lahan yang Dikuasai}

Hal-hal tersebut menunjukkan adanya tekanan pada sektor pertanian Jakarta. Penurunan tajam dari jumlah keluarga petani berlahan sangat sempit tersebut disebabkan oleh penguasaan lahan yang terlalu kecil, sehingga hasil pertaniannya sangat sulit diandalkan sebagai sumber penghasilan keluarga. Pada gilirannya, sebagian dari mereka memutuskan untuk benar-benar keluar dari sektor pertanian. Namun, dengan lahan sesempit itu, masih ada petani yang bertahan di sektor pertanian. Bagi keluarga petani 
sangat gurem, pertanian masih menjadi penopang hidup meskipun mereka harus mencari sumber pendapatan di luar pertanian. Oleh karena itu, di tengah proses urbanisasi yang cepat dan menekan pertanian perkotaan, perlu dicatat bahwa pertanian perkotaan di Jakarta masih mampu memasok sebagian kebutuhan pangan dan sumber pendapatan terutama bagi keluarga petani yang menggarap lahan sangat sempit, dan tidak tersedia cukup alternatif pekerjaan di sektor lain yang menyerapnya. Dalam konteks ini, fungsi pertama pertanian sebagai sektor yang memenuhi kebutuhan makanan bagi penduduknya tetap ada, bahkan fungsi pemenuhan kebutuhan makanan ini menjadi penting bagi kelompok sosial tertentu yang hidup secara marjinal.

\section{Berkembangnya Fungsi-Fungsi Selain Penyedia Pangan}

Proses yang terjadi secara dinamis pada pertanian perkotaan tidak tunggal. Proses tersebut bukan hanya proses spasial urbanisasi yang mengonsumsi lahan-lahan tidak terbangun, tetapi juga terjadi proses-proses lain dari pertanian perkotaan, yang bisa bersifat berlawanan (conflicting), seiring sejalan (complementary), atau mendukung satu dengan yang lainnya (supportive) (Kebir \& Barraqué, 2014).

Dalam kasus Jakarta, urbanisasi yang begitu cepat khususnya sejak era Orde Baru telah mengubah lanskap kawasan perkotaan. Luas ruang terbuka hijau di Jakarta relatif kecil. Hasilnya adalah pada tahun 1996, satu tahun sebelum krisis ekonomi (Krisis Moneter), luas lahan terbangun adalah sekitar 42 ribu hektar, atau sekitar $64,5 \%$ dari total wilayah Jakarta. Permukiman yang mendominasi lahan terbangun yaitu 34 ribu hektar, atau $82 \%$ dari total lahan terbangun. Sementara itu, luas lahan tidak terbangun adalah $35.5 \%$ dari total wilayah Jakarta. Sepuluh tahun setelah awal Krisis Moneter, pada tahun 2007 terdapat perubahan luas lahan terbangun menjadi kurang lebih 50 ribu hektar atau sekitar $76 \%$ dari total wilayah Jakarta. Permukiman mendominasi lahan terbangun yaitu 42 ribu hektar, atau $84 \%$ dari total lahan terbangun. Sementara itu, lahan tidak terbangun mencapai 24\% (Tambunan, 2011).

Badan Pusat Statistik (BPS) Kota Jakarta melalui Sensus Pertanian 2013 belum menyediakan data luas lahan pertanian di Indonesia, termasuk Jakarta. Sementara itu, Tambunan (2011) membuat estimasi luas lahan pertanian yang terlalu tinggi yaitu 18 ribu hektar atau sekitar 28,4\% dari total wilayah Jakarta pada tahun 1996, dan 14 ribu hektar atau $22.4 \%$ dari total wilayah Jakarta pada tahun 2007. Tambunan (2011) menganggap lahan tidak terbangun adalah lahan pertanian, padahal tidak semua lahan tidak terbangun memiliki fungsi pertanian. Selain itu, pembangunan properti yang terus meningkat di Jakarta menunjukkan bahwa proses peningkatan lahan tidak terbangun menjadi lahan terbangun terus terjadi (Hudalah \& Firman, 2012).

Hal tersebut menunjukkan bahwa lahan-lahan pertanian di Jakarta semakin terdesak dan dikonversi menjadi lahan terbangun, sehingga menurunkan luas daerah resapan air hujan yang dapat meningkatkan risiko banjir. Sementara itu, Jakarta semakin padat, panas, dan kotor karena aktivitas ekonomi dari penduduk yang terus bertambah. Hal tersebut menyebabkan polusi dan kondisi udara yang tidak sehat bagi penduduk Jakarta. Oleh karena itu, Jakarta tetap membutuhkan ruang terbuka hijau. Ruang terbuka yang dikelola dengan cara ditanami sehingga terlihat hijau dan memproduksi oksigen dan menyerap sebagian $\mathrm{CO}_{2}$. Hal tersebut dapat diwujudkan melalui pertanian perkotaan sebagai salah satu cara mengatasi tekanan yang diakibatkan oleh urbanisasi. Pertanian dapat memberi nilai baru yang berbeda dari nilai tradisional sebelumnya, yaitu semata-mata sebagai penyedia makanan, khususnya makanan pokok. Nilai-nilai ini menempatkan pangan tidak lagi menjadi isu utama, tetapi pertanian mengaitkan dirinya pada nilai-nilai kekotaan, sehingga fungsi penyedia pangan tidak hilang tetapi bertransformasi. Dalam transformasi ini pertanian perkotaan harus dianggap multifungsi dan terkait dengan lingkupnya yaitu kategori ruang terbuka tidak terbangun di kota. 


\section{Keragaman Fungsi dan Bentuk Spasial Pertanian Kota (Studi Kasus: Pertanian Kota di Jakarta)}

Pertanian dalam bentuk apapun baik padi-nonpadi, pangan-nonpangan, dan sawahnonsawah memberikan nilai utama yaitu mengokupasi ruang terbuka tidak terbangun tersebut sehingga layak dikategorikan sebagai ruang terbuka hijau. Praktik semacam ini adalah suatu nilai baru dalam perkotaan yang berkembang di dunia dan perlu diadopsi oleh Pemerintah Daerah DKI Jakarta (Pemda DKI) dan bahkan pemerintah pusat. Secara nyata penduduk Jakarta dari berbagai kelas sosial dan kelas pendapatan membutuhkan lingkungan yang hijau. Hal tersebut menunjukkan bahwa pertanian perkotaan memiliki fungsi ekologis yang bertujuan untuk melestarikan lingkungan.

Dalam konteks tersebut, menurunnya luas lahan padi mengkhawatirkan Pemda DKI karena jika terus menurun, suatu saat sawah bisa habis di Jakarta. Perhatian lebih mulai diberikan oleh Pemda DKI dengan cara memberikan bantuan benih dan pupuk kepada para petani sebagai insentif agar mereka tetap bertani. Selain itu, Pemda DKI membiarkan para petani mengelola lahan kosong (vacant land), baik milik Pemda DKI maupun swasta, untuk digunakan sebagai lahan pertanian termasuk sawah (Purnomohadi, 1998). Pemda DKI hanya meminta para petani harus segera pergi ketika lahan akan dipakai (Purwanto, 2010).

Selain itu, pihak swasta membiarkan tanah-tanah yang dimilikinya sebagai ruang terbuka sebagai sarana investasi yang diharapkan harganya terus naik. Selama lahan tidak dipakai, kebanyakan perusahaan tidak keberatan tanahnya digarap oleh para petani tersebut karena mereka membantu pemilik tanah menjaga klaim atas tanahnya secara de facto, yaitu mendudukinya. Selain itu, pemilik tanah mempunyai sertifikat sebagai klaim de jure. Para petani ini berbeda dengan "penjaga swasta" yang meminta "upah tunggu". Sebagian dari "penjaga swasta" ini kurang bisa dipercaya oleh perusahaan karena mereka adalah "preman". Namun demikian, para petani yang menggarap lahan tersebut sesungguhnya merasa khawatir dengan keberlanjutan mata pencaharian mereka di masa mendatang karena lahan tersebut sewaktu-sewaktu bisa dibangun oleh pemiliknya sehingga mereka harus pergi. Hal tersebut menunjukkan fungsi lain dari pertanian perkotaan yang mempunyai fungsi sosial sebagai "penjaga" vacant land yang dimiliki oleh pemerintah maupun swasta agar tidak diserobot oleh pihak lain.

\section{Keragaman Bentuk-Bentuk Spasial Pertanian perkotaan}

Pertanian perkotaan memiliki fungsi jamak (multifungsi) yang tercermin dari bentuk fisik tidak tunggal (multiform) yang menempati ruang-ruang kota. Distribusi keragaman bentuk-bentuk spasial pertanian perkotaan dapat dilihat pada Gambar 6. Adapun pembahasan keragaman bentuk spasial pertanian perkotaan ditampilkan dalam dua kategori yaitu bentuk spasial pertanian sawah dan nonsawah, yang akan dijelaskan pada subbagian berikut ini.

\section{Bentuk Spasial Pertanian Padi}

Di Jakarta, bentuk spasial pertanian padi yang khas adalah petak-petak sawah dengan tanaman padi yang dikelilingi oleh lahan terbangun (terutama industri dan permukiman) (Gambar 7). Tekanan urbanisasi membuat petak-petak sawah tersebut tidak ditemui di seluruh wilayah kota dan hanya tersebar di tiga kota saja (Jakarta Barat, Jakarta Utara, Jakarta Timur). Dalam mempertahankan keberadaan sawah, Pemda DKI menghimbau agar lahan sawah yang ditanami petani tetap berfungsi sebagai sawah (tidak dialihfungsikan), kecuali pemilik tanah yang dijadikan sawah tersebut benar-benar ingin membangunnya (mengalihfungsikan lahan). Pada kawasan industri Cakung-Cilincing yang padat, Pemda DKI mendorong perlindungan bagi petak-petak sawah yang tersisa di sana (Gambar 8). Keberadaan sawah memiliki arti khusus karena padi adalah makanan pokok dan menjadi simbol pertanian. 


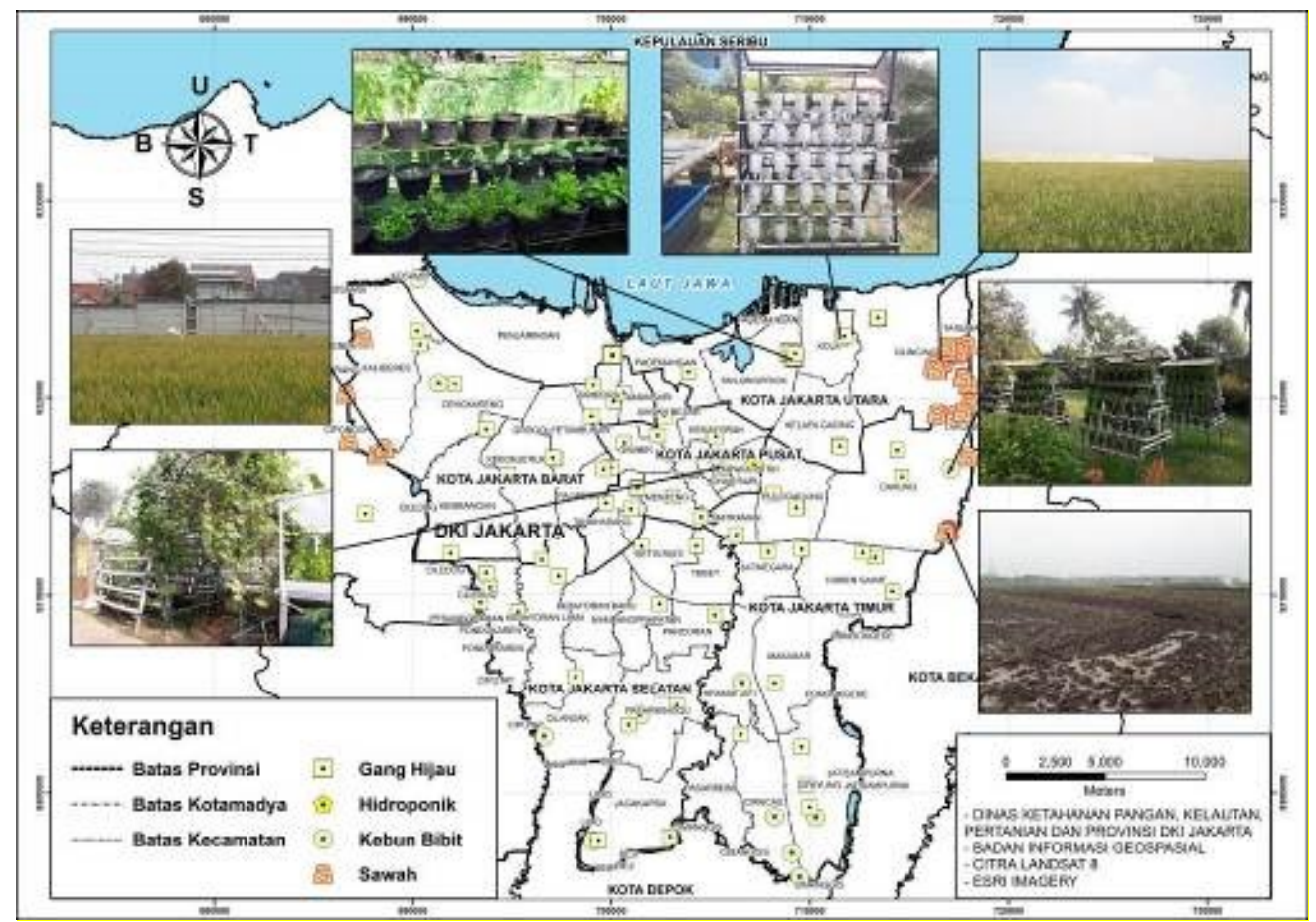

Sumber: Kompilasi Survey Lapangan, 2018;, BIG, 2016;, Earth Explorer, 2018

\section{Gambar 6. Distribusi Keragaman Bentuk Spasial Pertanian Perkotaan di Jakarta}

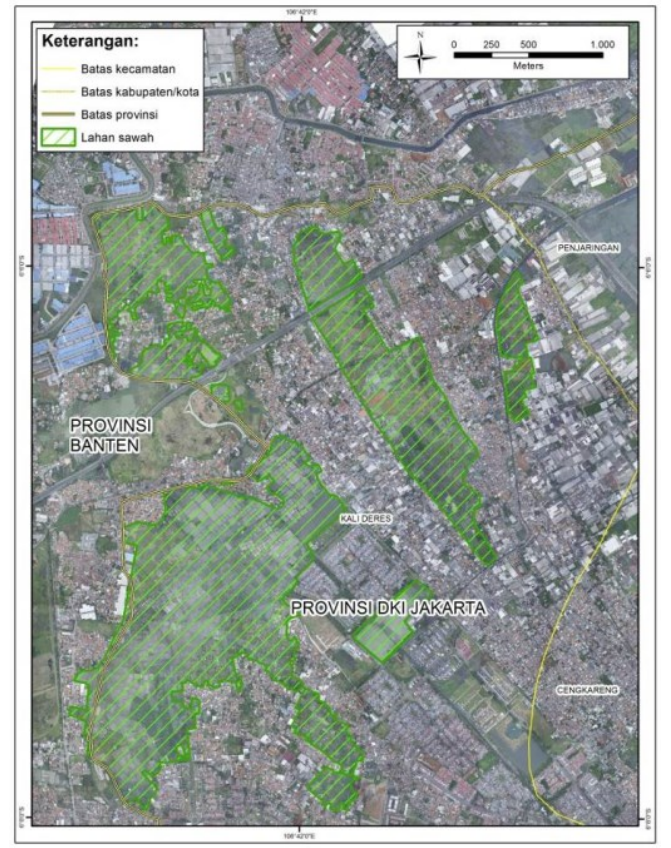

Sumber: Modifikasi Citra Quick Bird Google Earth, 2015

Gambar 7. Bentuk Spasial Lahan Yang Dikelilingi Lahan Terbangun (Industri dan Permukiman) di Jakarta Barat 


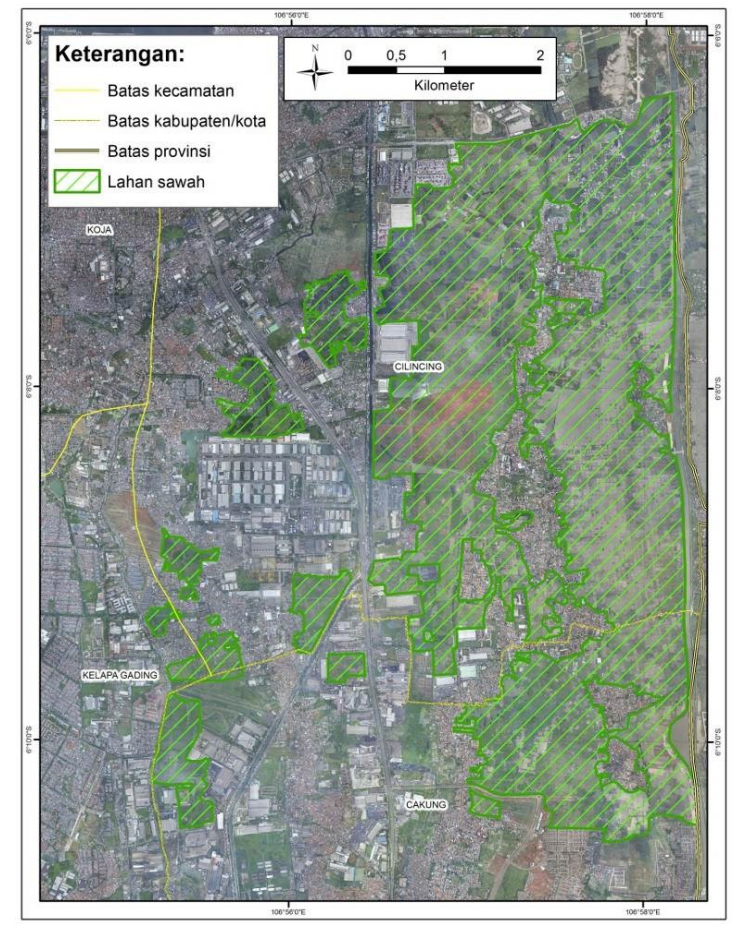

Sumber: Modifikasi Citra Quick Bird Google Earth, 2015

\section{Gambar 8. Bentuk Spasial Lahan Sawah di Perbatasan Jakarta Utara dan Jakarta Timur (Cakung-Cilincing)}

Selain itu, dalam rangka mempertahankan sawah agar tidak hilang dari Jakarta, Pemda DKI merasa perlu mengambil tindakan langsung yaitu mengakuisisi lahan sawah. Di Ujung Menteng, Jakarta Timur, Pemda DKI membeli lahan sawah seluas 20 hektar dan menyerahkan pengelolaannya kepada para petani. Hal ini adalah pertama kalinya Pemda DKI memiliki lahan sawahnya sendiri. Sebelumnya, ada suku dinas terkait sektor pertanian (yang namanya berganti-ganti, sekarang Suku Dinas Ketahanan Pangan, Kelautan, dan Pertanian), tetapi perannya lebih sebagai pamong dan regulator. Saat ini, walaupun kecil, Pemda DKI telah memulai nasionalisasi sawah (Suryanis, 2014).

\section{Bentuk Spasial Pertanian Tanaman Nonpadi}

Urbanisasi memang menimbulkan konversi lahan yang menaikkan jumlah lahan terbangun di perkotaan yang mendesak lahan pertanian. Bangunan-bangunan semakin memadati kota sehingga mendorong terjadinya transformasi bentuk spasial pertanian tanaman nonpadi. Transformasi bentuk spasial pertanian tanaman nonpadi yang dibahas dengan menganalisis beberapa contoh, seperti gang hijau dan hidroponik.

\section{Gang Hijau}

Konversi lahan tidak terbangun menjadi lahan terbangun yang terjadi secara kontinu di Kota Jakarta telah menyebabkan munculnya bangunan-bangunan dan permukiman padat penduduk. Akibatnya, Jakarta menjadi panas dan tidak hijau. Hal tersebut mendorong Dinas Ketahanan Pangan, Kelautan dan Pertanian (DKPKP) Provinsi DKI Jakarta meluncurkan program untuk mengajak warga melakukan kegiatan pertanian perkotaan pada tahun 2016. Minimnya lahan pertanian tersebut mendorong DKPKP untuk mengajak warga melakukan kegiatan pertanian perkotaan tersebut di gang-gang yang ada di Jakarta. Oleh karena itu, program tersebut diberi nama Program Gang Hijau. Selain 
berfungsi sebagai sarana penghijauan, tujuan utama dari program ini adalah agar warga dapat menanam tanaman hortikultura khususnya cabai sebagai upaya untuk mengatasi inflasi akibat tingginya harga cabai, dan memenuhi kebutuhan sebagian pangan keluarga dari hasil pertanian sendiri. DKPKP bermitra dengan Bank Indonesia untuk memberikan penyuluhan dan bantuan input pertanian seperti bibit, pupuk, pembasmi hama, dan lainlain.

Pertanian Gang Hijau tersebut menunjukkan bentuk spasial yang khas karena dilakukan di permukiman padat penduduk. Oleh karena itu, teknik pertanian bertingkat (vertikultur) diterapkan untuk mengatasi terbatasnya lahan pertanian yang berbasis tanah (landed agriculture) (Gambar 6). Evaluasi dan penyesuaian pelaksanaan program tersebut masih terus dilaksanakan, sehingga tingkat keberhasilannya belum dapat dipastikan. Hasil observasi di lapangan menunjukkan pro dan kontra terhadap program tersebut. Masyarakat yang memang senang bertani dan merasakan manfaat dari kegiatan pertanian tersebut menyambut baik program tersebut. Sementara itu, masyarakat yang kontra menganggap pot-pot yang disusun secara vertikal dan diletakkan di gang yang sempit mengganggu aksesibilitas menuju rumah mereka. Oleh karena itu, perlu dilakukan edukasi kepada masyarakat akan pentingnya melakukan pertanian perkotaan.

\section{Hidroponik}

Bentuk spasial pertanian perkotaan di Jakarta lainnya adalah pertanian hidroponik, yaitu suatu budidaya tanpa media tanam tanah namun menggunakan media tanam air. Pada sistem ini, kebutuhan air lebih sedikit daripada media tanah sehingga lebih efisien dan mampu memenuhi nilai ekologi urban yaitu hemat air. Namun, biaya pembelian alat-alat hidroponik yang baik, relatif lebih mahal daripada biaya bertani di tanah. Di Jakarta, pertanian hidroponik dikonsumsi dan dipraktikkan oleh kelas menengah dan atas sebagai bagian dari fungsi leisure (kesenangan) yaitu hobi berkebun. Hasil wawancara menunjukkan nilai ekologis penghematan air dapat digabungkan dengan fungsi vertikultur, yaitu suatu pertanian bertingkat yang menghemat ruang perkotaan. Irigasi dilakukan secara modern dengan menggunakan saluran pipa PVC dan mesin sirkulasi air (Gambar 9).

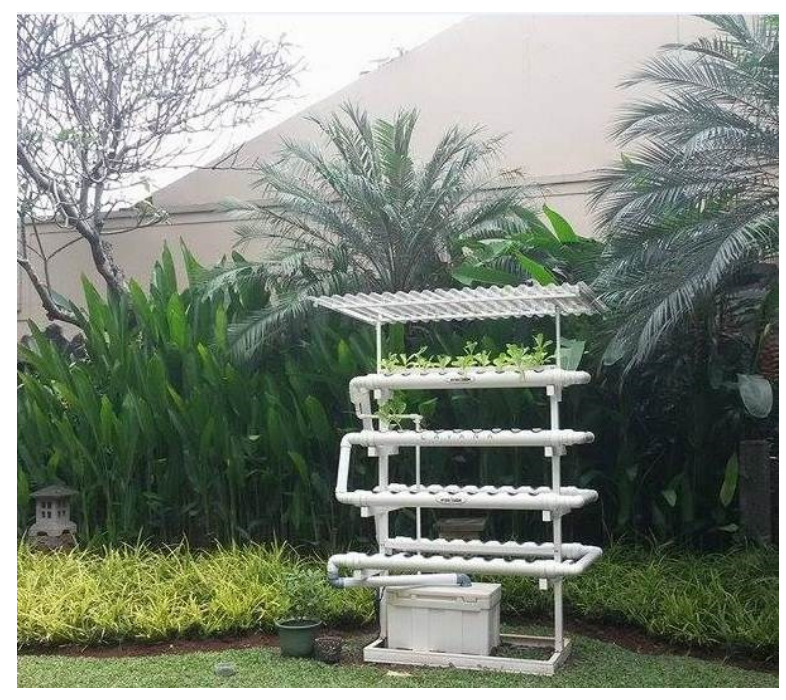

Sumber: Dokumentasi Observasi Lapangan, 2018

\section{Gambar 9. Vertikultur di Permukiman Mewah di Jakarta}

Namun demikian, pertanian hidroponik ini dilakukan untuk tujuan komersial walaupun pada awalnya diinisiasi oleh DKPKP melalui pemberian bantuan rak hidroponik. 
Namun, permasalahan keterbatasan lahan tidak menghalangi warga di Cempaka Putih Timur untuk melakukan kegiatan pertanian perkotaan, yang dilakukan dengan memanfaatkan lahan di pinggir Kali Sunter untuk dijadikan tempat pertanian hortikultura menggunakan teknologi hidroponik bertingkat (Gambar 6). Adapun jenis sayuran yang ditanam adalah kailan, kale, sawi hijau, pokcay, dan lain-lain. Hasil pertanian hidroponik tersebut ada yang dikonsumsi sendiri dan ada yang diolah sebagai bahan pembuatan mie ayam hijau. Selain itu, ada yang dijual dengan sistem pemesanan sebelum panen ke warga sekitar Cempaka Putih dan sebagian untuk memasok kebutuhan hotel. Berdasarkan hasil wawancara, belum ada pencatatan yang terorganisasi mengenai jumlah total kilogram produksi pertanian dan berapa penghasilan yang didapatkan dari kegiatan tersebut, sehingga ke depannya perlu dilakukan pendampingan terkait pengelolaan budidaya dan pemasaran hasil pertanian.

\section{Kesimpulan}

Pertumbuhan penduduk yang tinggi di perkotaan, khususnya di Provinsi DKI Jakarta, mendorong peningkatan permintaan akan tanah untuk permukiman, bisnis, dan pusat perbelanjaan. Hal ini menyebabkan nilai tanah untuk kegiatan tersebut lebih tinggi dibandingkan nilai tanah untuk aktivitas pertanian. Oleh karena itu, konversi lahan pertanian menjadi lahan terbangun tidak dapat dihindari. Konversi lahan tersebut telah mengakibatkan degradasi lingkungan sehingga kota mengalami permasalahan lingkungan seperti banjir, polusi udara, dan pemanasan perkotaan (urban heat). Hal tersebut mengancam keberlanjutan kehidupan di perkotaan. Pertanian perkotaan pada dasarnya memiliki keragaman fungsi, dan memiliki potensi untuk menjawab ancaman terhadap keberlanjutan pertanian perkotaan Jakarta.

Pertanian perkotaan di Jakarta memiliki keragaman fungsi dan keragaman bentuk spasial. Fungsi tradisional pertanian sebagai penyedia pangan masih bertahan. Hal ini ditunjukkan dengan aktivitas pertanian tanaman padi yang merupakan makanan pokok masih dapat ditemukan walaupun marjinal secara spasial. Fungsi-fungsi selain penyediaan pangan berkembang seiring dengan perkembangan kota. Di satu sisi, perkembangan kota menekan pertanian. Namun di sisi lain, perkembangan kota memungkinkan berkembangnya fungsi-fungsi selain penyediaan pangan yang memberikan nilai-nilai kekotaan yang baru tercipta di tengah-tengah dampak negatif urbanisasi seperti pemanasan kota, polusi, dan padatnya kota.

Fungsi-fungsi nonpangan yang diidentifikasi di Jakarta meliputi fungsi-fungsi kelestarian lingkungan (ekologi) seperti penyedia oksigen dan resapan air; fungsi sosialekonomi seperti penjaga klaim properti seperti pada lahan tidur dan rumah kosong; dan fungsi budaya seperti pemenuhan kerinduan akan buah matang di pohon. Fungsi penyediaan pangan, khususnya makanan pokok, tidak lagi utama, tetapi bertransformasi dan melebur dengan fungsi-fungsi lainnya. Dengan demikian, pertanian perkotaan Jakarta mampu beradaptasi dalam lingkungan fisik dan nonfisik di kotanya.

Sebagai rekomendasi, pemerintah dan para perencana Kota Jakarta perlu lebih memberi perhatian pada penciptaan nilai-nilai lain pertanian sehingga keragaman fungsi dan bentuk-bentuk spasial dari pertanian perkotaan tidak dianggap sebagai kelemahan, namun justru sebagai kelebihan. Keragaman fungsi dan bentuk pertanian perkotaan ini perlu dipertimbangkan dalam pengambilan kebijakan perencanaan kota yang holistik dan komprehensif demi terwujudnya pembangunan kota yang berkelanjutan. Oleh karena itu, integrasi pertanian perkotaan dalam kebijakan perencanaan kota perlu melibatkan berbagai pemangku kepentingan, tidak hanya Dinas Ketahanan Pangan, Kelautan dan Pertanian, namun juga pihak-pihak atau instansi lain yang terkait.

Dalam mendetailkan gambaran mengenai keragaman fungsi dan bentuk-bentuk spasial pertanian perkotaan yang ada di Jakarta, maka diperlukan penelitian-penelitian 
lanjutan dengan unit analisis yang lebih kecil pada level kota, kecamatan, bahkan kelurahan. Selain itu penelitian-penelitian lanjutan perlu dilakukan pada level subsektor pertanian yang lain seperti padi, palawija, dan hortikultura.

\section{Ucapan Terima Kasih}

Penulis mengucapkan terimakasih kepada Departemen Geografi, FMIPA-UI yang telah mendanai penelitian ini melalui Hibah Penelitian Dosen Muda. Selain itu, penulis juga berterimakasih kepada Dinas Ketahanan Pangan, Kelautan dan Pertanian (DKPKP) Provinsi DKI Jakarta yang telah membantu penelitian ini.

\section{Daftar Pustaka}

Aubry, C., Ramamonjisoa, J., Dabat, M. H., Rakotoarisoa, J., Rakotondraibe, J., \& Rabeharisoa, L. (2012). Urban agriculture and land use in cities: An approach with the multi-functionality and sustainability concepts in the case of Antananarivo (Madagascar). Land Use Policy, 29(2), 429-439. doi:10.1016/j.landusepol.2011.08.009.

Badan Perencanaan dan Pembangunan Daerah (BAPPEDA) Provinsi DKI Jakarta. (2018). Rencana pembangunan jangka menengah daerah Provinsi DKI Jakarta tahun 2018-2022. Retrieved June 4, 2018, from https://bappeda.jakarta.go.id//rpjmd/front\#exsum.

Badan Pusat Statistik (BPS) Provinsi DKI Jakarta. (2013). Laporan hasil sensus pertanian 2013 (pencacahan lengkap). Jakarta: Badan Pusat Statistik Provinsi DKI Jakarta.

Badan Pusat Statistik (BPS) Provinsi DKI Jakarta. (2014). Statistik daerah Provinsi DKI Jakarta 2014. Jakarta: Badan Pusat Statistik Provinsi DKI Jakarta.

Butler, D. R. (1994). Repeat photography as a tool for emphasizing movement in physical geography. Journal of Geography, 93(3), 141-151. doi:10.1080/00221349408979710.

Campbell, L. K. (2016). Getting farming on the agenda: Planning, policymaking, and governance practices of urban agriculture in New York City. Urban Forestry \& Urban Greening, 19, 295-305. doi:10.1016/j.ufug.2016.03.011.

Drechsel, P., \& Dongus, S. (2010). Dynamics and sustainability of urban agriculture: Examples from subSaharan Africa. Sustainability Science, 5(1), 69-78. doi:10.1007/s11625-009-0097-x.

Dubbeling, M., de Zeeuw, H., \& van Veenhuizen, R. (2010). Cities, poverty and food; Multi-stakeholder policy and planning in urban agriculture. Warwickshire: Practical Action Publishing.

Hudalah, D., \& Firman, T. (2012). Beyond property: Industrial estates and post-suburban transformation in Jakarta Metropolitan Region. Cities, 29(1), 40-48. doi:10.1016/j.cities.2011.07.003.

Kebir, L., \& Barraqué, B. (2014). Editorial. Espaces et Sociétés, 158(3), 9-12. doi:10.3917/esp.158.0007.

Kementerian Pertanian Republik Indonesia. (2016). Data luas lahan, produksi dan produktivitas lahan tanaman padi sawah di Provinsi DKI Jakarta.

Li, Z., Anderson, W., Yang, P., Wu, W., Tang, H., \& You, L. (2015). Chinese rice production area adaptations to climate changes, 1949-2010. Environmental Science and and Technology, 49(4), 2032-2037. doi:10.1021/es505624x.

Lovell, S. T. (2010). Multifunctional urban agriculture for sustainable land use planning in the United States. Sustainability, 2, 2499-2522. doi:10.3390/su2082499.

Mollard, A. (2003). Multifonctionnalité de l'agriculture et territoires: des concepts aux politiques publiques. Les Cahiers de La Multifonctionnalité, 1, 37-56.

Nahmias, P., \& Le Caro, Y. (2012). Pour une définition de l'agriculture urbaine: Réciprocité fonctionnelle et diversité des formes spatiales. Environnement Urbain/Urban Environment, 6, 1-16.

Pemerintah Republik Indonesia. (2008). Peraturan Pemerintah Nomor 26 Tahun 2008 tentang Rencana Tata Ruang Wilayah Nasional. Retrieved from http://jdih.esdm.go.id/peraturan/PP No. 26 Thn 2008.pdf

Peng, J., Liu, Z., Liu, Y., Hu, X., \& Wang, A. (2015). Multifunctionality assessment of urban agriculture in Beijing City, China. Science of the Total Environment, 537, 343-351. doi:10.1016/j.scitotenv.2015.07.136. 


\section{Keragaman Fungsi dan Bentuk Spasial Pertanian Kota (Studi Kasus: Pertanian Kota di Jakarta)}

Perring, M. P., Standish, R. J., Hulvey, K. B., Lach, L., Morald, T. K., Parsons, R., ... Hobbs, R. J. (2012). The Ridgefield Multiple Ecosystem Services Experiment: Can restoration of former agricultural land achieve multiple outcomes? Agriculture, Ecosystems and Environment, 163, 14-27. doi:10.1016/j.agee.2012.02.016.

Pribadi, D. O., \& Pauleit, S. (2016). Peri-urban agriculture in Jabodetabek Metropolitan Area and its relationship with the urban socioeconomic system. Land Use Policy, 55, 265-274. doi:10.1016/j.landusepol.2016.04.008.

Purnomohadi, N. (1998). Jakarta: Urban Agriculture as alternative strategy to face the economic crisis. Retrieved February 1, 2017, from http://www.ruaf.org/sites/default/files/Jakarta_1.PDF.

Purwanto, S. A. (2010). Bertani di kota, berumah di desa: Studi kasus pertanian kota di Jakarta Timur. Universitas Indonesia.

Rose, G. (2008). Using photographs as Illustrations in human geography. Journal of Geography in Higher Education, 32(1), 151-160. doi:10.1080/03098260601082230.

Sidaway, J. D. (2002). Photography as geographical fieldwork. Journal of Geography in Higher Education, 26(1), 95-103. doi:10.1080/03098260120110395.

Stasiun Klimatologi Pondok Betung. (2010). Data curah hujan bulanan di Jakarta. Jakarta.

Suryanis, A. (2014). Jakarta ternyata punya sawah abadi. Retrieved December 1, 2017, from https://metro.tempo.co/read/581507/jakarta-ternyata-punya-sawah-abadi/full\&view=ok.

Tambunan, M. P. (2011). Kaitan penggunaan lahan perkotaan dengan banjir: Studi kasus: di Provinsi DKI Jakarta tahun 1996, 2002, dan 2007. In Seminar Nasional dan Pertemuan Ilmiah Tahunan XIV Ikatan Geografi Indonesia di Universitas Pendidikan Ganesha (11 November 2011). Singaraja, Bali: Universitas Pendidikan Ganesha.

Wu, W., Verburg, P. H., \& Tang, H. (2014). Climate change and the food production system: Impacts and adaptation in China. Regional Environmental Change, 14(1), 1-5. doi:10.1007/s10113-013-0528-1. 